\title{
Corrigendum: Chemotaxis towards autoinducer 2 mediates autoaggregation in Escherichia coli
}

\author{
Leanid Laganenka, Remy Colin \& Victor Sourjik
}

Nature Communications 7:12984 doi: 10.1038/ncomms12984 (2016); Published 30 Sep 2016; Updated 15 Dec 2016

Two previous studies describing the effects of autoinducer 2 (AI-2) on biofilm formation and chemotaxis in Escherichia coli were inadvertently omitted from the reference list of this Article. A reference to these studies along with ref. 27 should have been provided in the Introduction, as follows: 'It has been previously reported that, in E. coli, AI-2 can modulate biofilm formation (González-Barrios et al. 2006) and virulence-related phenotypes such as chemotaxis, swimming motility and attachment to host cells in vitro (Bansal et al. 2008, ref. 27).' These findings should have also been mentioned in the Abstract, where the physiological role of AI-2 in E. coli and other bacteria is referred to, and in the sections discussing motility, chemotaxis and biofilm formation in E. coli.

González Barrios, A. F. et al. Autoinducer 2 controls biofilm formation in Escherichia coli through a novel motility quorum-sensing regulator (MqsR, B3022). J. Bacteriol. 188, 305-316 (2006).

Bansal, T., Jesudhasan, P., Pillai, S., Wood, T. K. \& Jayaraman, A. Temporal regulation of enterohemorrhagic Escherichia coli virulence mediated by autoinducer-2. Appl. Microbiol. Biotechnol. 78, 811-819 (2008).

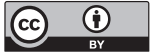

This work is licensed under a Creative Commons Attribution 4.0 International License. The images or other third party material in this article are included in the article's Creative Commons license, unless indicated otherwise in the credit line; if the material is not included under the Creative Commons license, users will need to obtain permission from the license holder to reproduce the material. To view a copy of this license, visit http://creativecommons.org/licenses/by/4.0/

(C) The Author(s) 2016 